Language in Africa 1(3), 2020, 373-404. doi: 10.37892/2686-8946-2020-1-3-373-404

\title{
ASPECTS OF THE PHONOLOGY AND MORPHOSYNTAX OF KYAK, AN ADAMAWA LANGUAGE OF NIGERIA
}

\author{
Matthew Harley \\ SIL Nigeria \\ matthew_harley@sil.org
}

\begin{abstract}
This paper provides a preliminary analysis of a few aspects of the phonology and morphosyntax of Kyak [bka], a largely undocumented Adamawa language spoken in the northern part of Taraba State in Nigeria. The paper is divided into four main sections. The first section deals with the phonology, focusing on consonant and vowel inventories, some phonetic processes, and syllable structure. The second section looks at nominal morphology, particularly nominal modifiers and possessive constructions, which show a distinction between alienable and inalienable possession. The third section describes the verbal morphosyntax, identifying the various forms that encode the expression of tense-aspect and person-number. The fourth part looks at a couple of clause/sentence level features, namely the clitic $-\boldsymbol{\eta}$, which is associated with the marking of assertiveness, and the use of logophoric pronouns. This is the first description of the phonological and grammatical features of the language, and one of the first for the Jen cluster. It thus adds to the knowledge of the cluster and to the evaluation of genealogical and areal hypotheses which involve languages of this region.
\end{abstract}

Key words: Kyak, Adamawa, phonology, morphology, tense, aspect, logophoric. 


\section{Introduction}

Kyak [bka] is an Adamawa language spoken by about $10,000^{1}$ people in the northern part of Taraba State in east-central Nigeria. Kyak [kják] is the endonym (autonym) for the community, while outsiders refer to both the people and the language using either Kyak or Bambuka, the latter being the name of a major town where Kyak is spoken. Kyak is one of ten almost completely undocumented languages belonging to the (Bikwin-)Jen subgroup, all spoken in the floodplain between the north bank of the Benue River and the Muri mountains at the intersection of Taraba, Gombe and Adamawa States (see Figure 1). Kyak is mainly spoken in Karim Lamido Local Government Area (LGA), but also in Jalingo, Lau, Zing and Ardo Kula LGAs in Taraba State, as well as in Lamurde, Demsa and Numan LGAs of Adamawa State. No significant population is reported in Gombe State. Its major towns are: Bambuka, Liangum, Boko, Lisa, Lida, Krack, and Bojim (all in Karim Lamido LGA), and the main local markets are at Bambuka, Gomu, Jen, Krack and Karim Lamido. The Kyak people have strong social links (e.g. shared markets, intermarriage) with several of the neighbouring language communities, particularly with Moo (Gwomu) [gwg], Leelau [ldk], Mingang Doso [mko], Dza (Jenjo) [jen] and Dadiya [dbd]. Its language vitality is currently estimated at 6a (vigorous) on the EGIDS scale (Eberhard et al. 2019), meaning that it is being learned by the vast majority of children within the community. There are no known dialect differences.

The only previous research on Kyak consists of two short comparative wordlists of the Jen cluster (Kleinewillinghöfer 1995/2015; Othaniel 2017). The research for this paper was carried out in Jos rather sporadically between 2010 and 2019, with the help of two language assistants, Mr. Nahnah Soji and Rev. Wilson Kura, both long-

${ }^{1}$ Blench (2019) gives a population of 10,000. A similar figure is reached by taking Adelberger's (1995) figure of 5,000, and applying an annual growth rate of 2.6\% (World Bank Group 2019). 


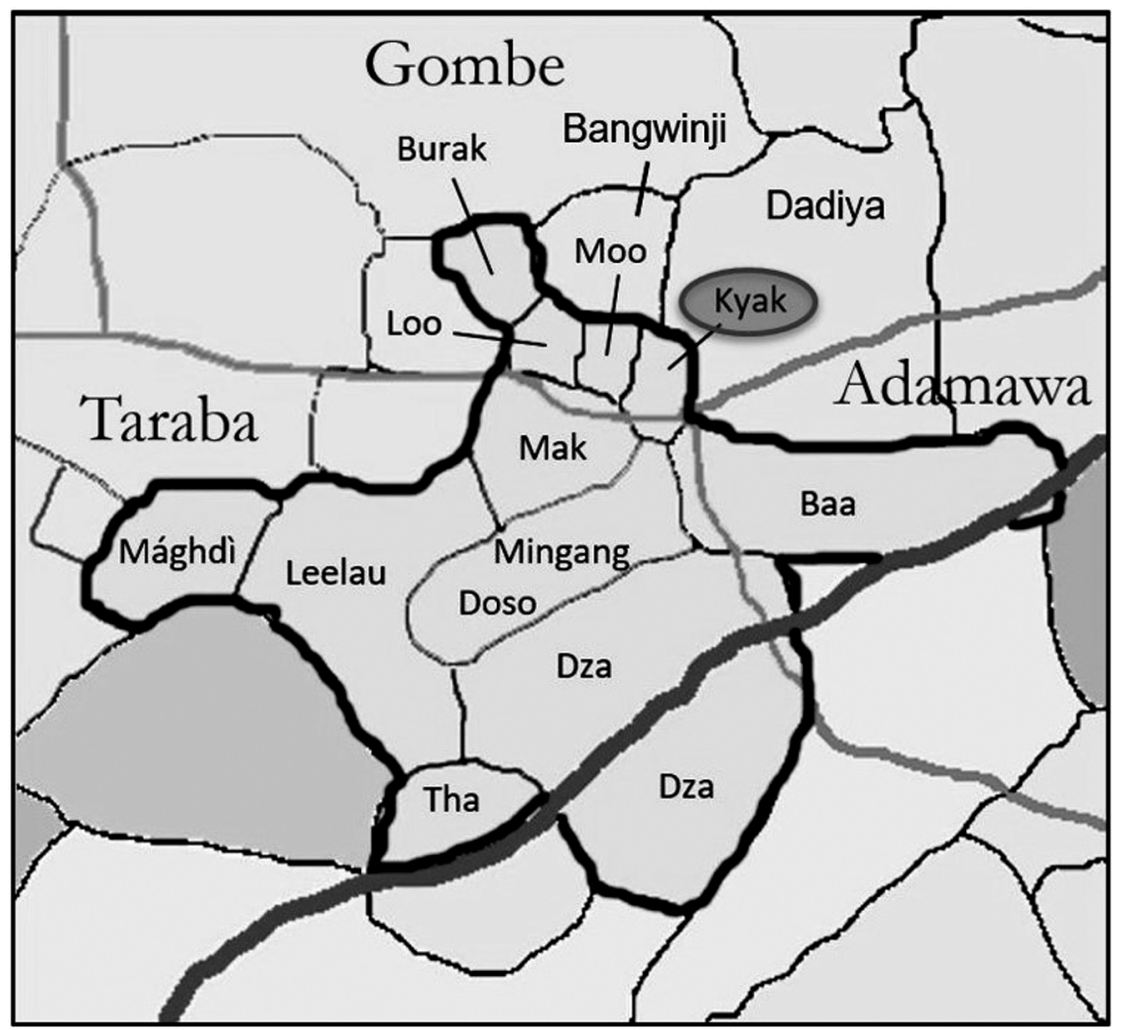

Figure 1. The (Bikwin-)Jen languages (adapted from Eberhard et al. 2019)

term residents of Liangum whose L1, L2 and L3 are Kyak, Hausa and English respectively. The analysis presented in this paper is based on a lexicon of roughly 700 words, about 30 pages of elicited grammatical data with recordings, and one fully glossed and transcribed folktale of about 3 mins in length. Given this relatively small data-set, the findings in this paper are still somewhat preliminary, particularly in the sections on morphology. The phonological and morphological topics discussed in this paper are included because they are foundational to under- 
standing the rest of the grammar, whilst the sections on assertiveness and logophoric pronouns are included because they arose during the analysis of the narrative text. I appreciate that in places, the analysis leaves many questions unanswered, but for reasons of space, these will have to be left for future research, for which these initial findings will hopefully serve as a solid foundation.

The paper is structured as follows: After a brief discussion of the genetic classification (\$2), I give an outline of the phonology and some phonological processes $(\S 3)$, followed by a discussion of some aspects of the nominal and verbal morphosyntax ( $\$ 4$ and $\S 5)$. I then examine one of the more unusual clause-level features (assertiveness/epistemicity) in $\S 6$, and one sentence-level feature (logophoric pronouns) in $\S 7$, before giving a conclusion in $\S 8$.

\section{Classification}

Kyak is unanimously reported to belong to the (Bikwin-)Jen subgroup, although there is little agreement on its higher level classification. The Glottolog (Hammarström et al. 2019) places it in a Waja-Jen subgroup within Central Gur, whilst the Ethnologue (Eberhard et al. 2019) classifies Waja-Jen as Adamawa. Furthermore, Kleinewillinghöfer (1996a; 2019) has questioned the validity of Waja-Jen itself, stating a lack of lexical and morphological evidence. Instead, he suggests the (Bikwin-)Jen subgroup is better placed within a broad North-western Adamawa Group within Adamawa-Gur. ${ }^{2}$

Within the (Bikwin-)Jen subgroup, which shows close to $50 \%$ internal lexical similarity, there is also considerable variation in classification. The Glottolog currently separates a Bikwin subgroup from a Jen subgroup, although Norton (2019) suggests that such

${ }^{2}$ The morphological links between Adamawa languages in the East and the Gur languages in the West, shown by Tula and Waja (Kleinewillinghöfer 1996b) have led some to doubt the distinction and instead talk about a larger AdamawaGur or Benue-Volta group (Kleinewillinghöfer 2019). 
a division is not supported by lexicostatistics. Instead he suggests that the (Bikwin-)Jen subgroup should be split into a northern subgroup comprising Burak-Loo, Maghdi and Mak, and a southern subgroup comprising Kyak-Moo-Leelau, Tha and Doso-Dza. In any case, all agree that Kyak's closest relatives are Moo [gwg] and Leelau [ldk], and that these two along with Kyak could, linguistically at least, be considered dialects of the same language, since their lexical similarity is above $90 \%$.

\section{Phonology}

This section describes various aspects of the phonology of Kyak, including the consonants $(\S 3.1)$, the vowels (\$3.2), the tones (\$3.3), vowel length ( $(3.4)$, distribution of segments $(\S 3.5)$, phonological processes (\$3.6), the interpretation of pre-pausal $[\varepsilon](\S 3.7)$, and the internal construction of nasalised vowels (\$3.8), before ending with some comments about the comparative phonology of the (Bikwin-)Jen subgroup (§3.9).

\subsection{Consonants}

The phonemic consonants of Kyak are shown in Table 1. Virtually all consonants occur phonemically labialised, but only labials occur phonemically palatalised. Othaniel's (2017) wordlist contains a few words with the additional consonants $[\mathrm{ts}],[\mathrm{dz}]$ and $[\mathrm{k}]$, but these invariably involve differences in transcription to my data.

The palatal implosive $/ f /$ is more accurately described as a voiced retroflex implosive $/ \mathfrak{d} /$, since the tongue is visibly curled back during pronunciation, but I've grouped it along with the other palatals because it functions like a palatal with respect to certain phonological processes (as shown in §3.6). Furthermore, the labialised alveolar implosive $/ \mathrm{d}^{\mathrm{w}} /$ may in fact be a labialised retroflex implosive $\left[\mathfrak{Q}^{\mathrm{w}}\right]$, since its auditory impression also has a distinct palatal quality. Kleinewillinghöfer $(1995 / 2015)$ transcribed it as $<$ dyw $>$, which may turn out to be a better orthographic option than $\langle\mathrm{dw}\rangle$, the other main possibility. 
Table 1

Kyak phonemic consonants

\begin{tabular}{|c|c|c|c|c|c|c|c|}
\hline & Labial & $\begin{array}{l}\text { Labio- } \\
\text { dental }\end{array}$ & $\begin{array}{l}\text { Alveo- } \\
\text { lar }\end{array}$ & Palatal & Velar & \begin{tabular}{|c|}
$\begin{array}{c}\text { Labio- } \\
\text { velar }\end{array}$ \\
\end{tabular} & $\begin{array}{c}\text { Glot- } \\
\text { tal }\end{array}$ \\
\hline $\begin{array}{l}\text { Stop/ } \\
\text { Affricate }\end{array}$ & $\begin{array}{ll}\mathrm{p} & \mathrm{b} \\
\mathrm{p}^{\mathrm{w}} & \mathrm{b}^{\mathrm{w}} \\
\mathrm{p}^{\mathrm{j}} & \mathrm{b}^{\mathrm{j}}\end{array}$ & & $\begin{array}{ll}\mathrm{t} & \mathrm{d} \\
\mathrm{t}^{\mathrm{w}} & \mathrm{d}^{\mathrm{w}}\end{array}$ & $\begin{array}{ll}\mathrm{t} \int^{\mathrm{w}} & \mathrm{d} 3 \\
\mathrm{t} \int^{\mathrm{w}} & \mathrm{d} \mathrm{z}^{\mathrm{w}}\end{array}$ & $\begin{array}{|ll|}\mathrm{k} & \mathrm{g} \\
\mathrm{k}^{\mathrm{w}} & \mathrm{g}^{\mathrm{w}} \\
\left(\mathrm{k}^{\mathrm{j}}\right) & \end{array}$ & kp gb & $?$ \\
\hline Implosive & $\begin{array}{l}6 \\
6^{w} \\
b^{j}\end{array}$ & & $\begin{array}{l}d \\
d^{w}\end{array}$ & $f$ & & & \\
\hline Fricative & & $\begin{array}{ll}f & v \\
f^{w} & \end{array}$ & $\begin{array}{ll}\theta / \mathrm{s} & \mathrm{\partial} / \mathrm{z} \\
\mathrm{S}^{\mathrm{w}} & \mathrm{Z}^{\mathrm{W}}\end{array}$ & & & & \\
\hline Nasal & $\begin{array}{l}\mathrm{m} \\
\mathrm{m}^{\mathrm{w}} \\
\mathrm{m}^{\mathrm{j}}\end{array}$ & & $\mathrm{n}$ & $\begin{array}{l}\mathrm{n} \\
\mathrm{n}^{\mathrm{w}}\end{array}$ & $\begin{array}{l}\eta \\
\eta^{w}\end{array}$ & & \\
\hline Approximant & & & 1 & $\mathrm{j}^{\mathrm{w}}$ & & $\mathrm{w}$ & \\
\hline Flap / Trill & & & $\mathrm{r} / \mathrm{r}$ & & & & \\
\hline
\end{tabular}

$[\mathrm{r}]$ and $[\mathrm{r}]$ are in free variation, although $[\mathrm{r}]$ is more common. $\left[\mathrm{k}^{\mathrm{j}}\right]$ is marginal, attested in just a single lexeme: [kjak] 'the Kyak community'.

\subsection{Vowels}

Kyak has eight oral vowels and three nasalised vowels, with a fourth nasalised vowel [ã] currently attested in just a few lexemes (e.g. k $k \hat{\tilde{a}}$

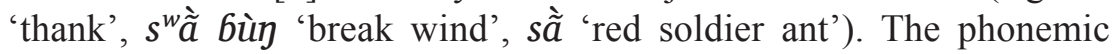
vowels of Kyak are shown in Table 2.

Othaniel (2017) also lists a high central vowel [i], as found in Dza [jen], but I have analysed it as an allophone of [ə].

\subsection{Tones}

Kyak has three contrastive lexical tones, High, Low, and Falling, as shown by the minimal triplet in (1). 
Table 2

Kyak phonemic vowels

\begin{tabular}{|c|c|c|c|c|c|c|}
\hline & \multicolumn{2}{|c|}{ Front } & \multicolumn{2}{|c|}{ Central } & \multicolumn{2}{|c|}{ Back } \\
\hline High & $\mathrm{i}$ & $\tilde{\mathbf{1}}$ & & & $\mathrm{u}$ & - \\
\hline Mid-High & $\mathrm{e}$ & - & & & o & - \\
\hline Central & & & ə & - & & \\
\hline Mid-Low & $\varepsilon$ & $\tilde{\varepsilon}$ & & & J & $\tilde{\mathrm{J}}$ \\
\hline Low & & & $\mathrm{a}$ & $(\tilde{a})$ & & \\
\hline
\end{tabular}

(1) a. sém 'pot'

b. sèm 'monkey'

c. sêm 'servant'

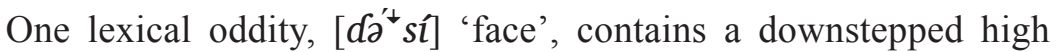
tone, presumably caused by a floating low tone trapped between the two high tones. Downstepped and upstepped high tones are quite common in phrases and sentences, as are phonetic mid tones, which are produced as a result of low-tone raising next to an adjacent high, among other processes, many of which are not yet well understood. In this paper, all examples are marked with surface tones, and a thorough analysis of tone sandhi is left for future research.

\subsection{Vowel length}

Vowel length does not appear to be contrastive, although long vowels are attested in a few lexemes (e.g. [wèè] 'inside', [bèc̀sć] 'young man', [náárè] 'seven'). It is possible that some of these have arisen from diphthongs with which they are in free variation (e.g. [wè̀] / [wèi] 'inside'), or are residual traces of lost syllables (cf. Moo: [nàndzērēe] 'seven'). There is also some variation in vowel length for the same lexical item. Sometimes this variation is used iconically for pragmatic effect, for example to represent the slowness of an action, as in (2). 


\section{(2) $u$ bè̀̀ nùy náá $g$-û $\quad k \dot{\varepsilon}$, \\ $3 \mathrm{SG} . \mathrm{PFV}$ pull thing own POSS-3SG DEM \\ ú dá à lò-ó}

3 SG.PFV put LOC head-POSS

'He (slowly) pulled his things onto his head (they were heavy).'

In this example, the vowel of the verb bì 'pull' is lengthened to represent the drawn out nature of the pulling, because of the heaviness of the load. If $b \grave{\varepsilon}$ was pronounced with a short vowel in this example, the duration of the pulling would not be indicated. (The lexeme ná 'own' in this example is also lengthened for emphasis). Elsewhere, notably with certain subject pronouns, there seems to be variation in vowel length for no clear reason. Othaniel (2017: 41-42) reports that it is hard to reconstruct long vowels across the Jen subgroup, and that some vowels transcribed as long may be the result of wordlist elicitation techniques (i.e. pronunciation in isolation).

\subsection{Distribution of consonants and vowels}

Any consonant can appear in the syllable onset position. Coda consonants are restricted to the following set: $/ \mathrm{p} /, / \mathrm{b} /, / \mathrm{k} /, / \mathrm{m} /, / \mathrm{n} /, / \mathrm{y} /$, $/ 1 /, / \mathbf{r} /, / \mathrm{j} /, / \mathrm{w} /$, and stops in this position are unreleased. Vowel segments are restricted to syllable nucleus position. Any vowel can occur in an open syllable, but only oral vowels are permitted in closed syllables. The maximal syllable template in $(\mathrm{C}) \mathrm{CV}(\mathrm{C})$. In initial CC clusters, the second $\mathrm{C}$ must be a liquid (either / $/ \mathrm{f}$ or /1/). Examples of different syllable types are given in Table 3.

Table 3

Attested syllable structures

\begin{tabular}{|c|c|c|c|c|c|}
\hline \multirow[b]{2}{*}{$z \grave{j}$} & \multirow[b]{2}{*}{ 'walk' } & \multicolumn{2}{|l|}{ CVC } & \multicolumn{2}{|c|}{$\mathrm{CCV}(\mathrm{C})$} \\
\hline & & zòk & 'elephant' & pràm & 'twist' \\
\hline ká & 'baboon' & bûy & 'tomorrow' & $g r \grave{\varepsilon}$ & 'chew' \\
\hline té & 'go' & bàr & 'snot' & plě & 'where' \\
\hline 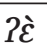 & 'sit' & $t \int^{w} \hat{a} b$ & 'small' & $k l \hat{\varepsilon}$ & 'certain' \\
\hline
\end{tabular}


Syllabic nasals occur only word-initially and are homorganic with the following consonant, as shown in (3).

\section{(3) a. ńdê 'all' \\ b. ̀̀g âm 'outside'}

The vast majority of morphemes are monosyllabic with the structure $\mathrm{CV}$ or CVC, with both types being extremely common. Very few words have more than two syllables. Compound nouns are very common, although as is usually the case, there is a continuum of how well fused the component parts have become. Some examples are given in (4).
a. $\quad s^{w} a ́ l \eta^{w} \grave{a} \quad$ 'lip'
lit. 'skin of mouth'
b. $\eta^{w} \grave{a} d^{\prime} \partial^{\downarrow} s i ́$ 'forehead'
lit. 'mouth/front of face'
c. bंày $\eta^{w} \grave{a} \quad$ 'beard'
lit. 'hair of mouth'

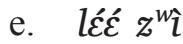
'vein'
lit. 'path of blood'

\subsection{Phonetic processes}

There is considerable allophonic variation among the vowel phonemes, triggered by the surrounding segments, with the central vowel /ə/ being particularly susceptible. Following a labialised consonant, /a/ is in free variation with either $[\mathrm{u}]$ or $[\mathrm{o}]$, with $[\mathrm{o}]$ being the variant preceding labial plosives, and $[\mathrm{u}]$ being the default variant, as shown in (5).
(5)
a. $\quad d^{w} \grave{\partial} l \rightarrow d^{w} \grave{\partial} l / d u ̀ l ~$ 'neck'
b. $k^{w} a ́ b \rightarrow k^{w} a ́ b / k^{w} o ́ b / k o ́ b$ 'thorn'

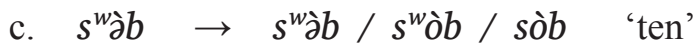

Following a palatal(ised) consonant, $/ \partial /$ is in free variation with either [i] or $[\mathrm{e}]$, with $[\mathrm{e}]$ being the variant preceding labial plosives, and [i] being the default variant, as shown in (6).
(6) a. fám $\rightarrow$ fim
'tongue'
b. bân $\rightarrow$ bîn
'star'
c. $t \hat{\partial} b \rightarrow t \hat{\partial} b / t \int e ̀ b$ 'tie' 
In closed syllables, /a/ often becomes [i], especially before an $/ \mathbf{r} /$, an $/ 1 /$, or adjacent to a velar consonant, as shown in (7).
(7) a. bàr
$\rightarrow$ bìr
'snot'
b. $d^{w}$ ’́r

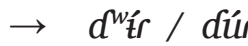
'nose'
c. bál
$\rightarrow$ bit
'rope'
d. kám
$\rightarrow$ kím
'kiss'
e. kákáb
$\rightarrow \quad k \hat{t} k \hat{t} b^{\top}$
'bones'
f. sáy / Aán
$\rightarrow$

Before a syllable containing a front vowel, /ə/ usually becomes [I] or [i], as shown in (8).

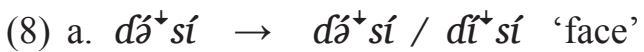

b. sábè $\rightarrow$ sábè / síbè 'hare'

c. dàlè $\rightarrow$ dàlè / dìlè 'leave'

High and low vowels are sometimes centralised in closed syllables, as shown in (9).
(9)
$\begin{array}{lll}\text { a. nùy } \rightarrow \text { nùy / nìn } & \text { 'thing', } \\ \text { b. vìn } \rightarrow \text { vìn / vìn } & \text { 'flower' }\end{array}$
c. mìn $\rightarrow \operatorname{mìn} / \operatorname{mìn}$ 'guinea corn'
d. kàp $\rightarrow$ kàp / kàp 'tree'
e. $t \int^{w} a ̂ b \rightarrow t f^{w} \hat{a} b / t \int^{w} \hat{a} b \quad$ 'small'

\subsection{The interpretation of pre-pausal $[\varepsilon]$}

The most striking phonological rule affecting vowel phonemes is that $/ \partial /$ is realised as $/ \mathcal{E} /$ before a pause (i.e. the distinction between $/ \mathrm{a} /$ and $/ \varepsilon /$ is neutralised prepausally). At first glance, looking at the data in (10) and (11), one might suppose that this was the wrong way round, and that $/ \mathcal{E} /$ was being centralised to /ə/ non-pre-pausally instead. 
(10) a. sć 'body'

b. sá-má

body-2sG.POSs

'your body'

(11) a. té ' go'

b. ú 'tá $g^{w} \hat{e}$

$3 \mathrm{SG} . \mathrm{PFV}$ go house

'He went home.'

However, it would then be difficult to explain why some other instances of $/ \varepsilon /$ are never centralised, as shown in (12).
a. lé 'tooth'
b. $\operatorname{l\varepsilon }^{\prime} \varepsilon^{-} m a^{3}$
tooth-2sG. POSS
'your tooth'

It seems that most verbs ending in an $[\varepsilon]$ underlyingly have a final $/ \partial /$, although other lexical categories are less predictable. One might argue that the $/ \varepsilon / \rightarrow[ə]$ rule still holds, but with a few lexical exeptions like that in (12), but then it would be slightly strange that /a/ never occurs before a pause even though /ə/ and / $/ \mathcal{E} /$ contrast word-medially. The simpler explanation is that $/ \partial / \rightarrow / \mathcal{E} /$, and that lexemes like [lé] 'tooth' contain a phonemic $/ \varepsilon /$, and so are not affected by the rule, although that still leaves the problem of why there are not more verbs which end in an underlying $/ \varepsilon /$. However, there is some evidence to support the $/ \partial / \rightarrow / \varepsilon /$ rule from comparative data. Cognates of words which show an allophonic $[\partial] /[\varepsilon]$ alternation in Kyak often contain an /ə/ or /i/ in closely related languages, as shown in Table 4.

${ }^{3} 3 \mathrm{I}$ am not sure why the root vowel is lengthened when the possessive suffix is added in this example. The downstepped high tone on the suffix is a result of a floating low tone carried by the suffix. 


\section{Table 4}

Cognates of words with an $[\ni] /[\varepsilon]$ alternation (Othaniel 2017)

\begin{tabular}{|l|c|c|c|c|c|c|}
\hline & Kyak & Moo & Leelau & Dza & Doso & Tha \\
\hline go & $t \hat{\varepsilon}$ & ta & ta & ta & ta & $d \grave{t}$ \\
\hline give & $d \grave{\varepsilon}$ & $d \grave{t}$ & $d \partial$ & ta & $d \partial$ & $d \partial$ \\
\hline
\end{tabular}

However, cognates of words which don't show an $[\partial] /[\varepsilon]$ alternation in Kyak do not always contain an /ə/ or /ì/, as shown in Table 5.

Table 5

Cognates of words without an $[\ni] /[\varepsilon]$ alternation (data from Othaniel 2017; Kleinewillinghöfer 1995/2015)

\begin{tabular}{|l|c|c|c|c|c|c|}
\hline & Kyak & Moo & Leelau & Dza & Doso & Tha \\
\hline mother & $n \hat{\varepsilon}$ & $n a$ & $n a$ & $n a$ & $n a$ & $n a$ \\
\hline tooth & $l \dot{\varepsilon}$ & $l \varepsilon$ & ləi/lei & - & - & - \\
\hline three & $t \grave{\varepsilon}$ & $t \varepsilon$ & təi/tai & (bwaa)tə/ta & nətə/nataa & nətə/nata \\
\hline
\end{tabular}

Another process affecting vowels is a restricted form of ATR harmony within morphemes, such that the -ATR mid-vowels [ $\varepsilon]$ or [ว] can only be followed by another -ATR vowel, although they can follow both +ATR and -ATR vowels. However, most morphemes are monosyllabic, and mid vowels are much less common than other vowels anyway, so vowel harmony is not a particularly significant feature of the language.

\subsection{Internal reconstruction of nasalised vowels}

It is possible that some nasalised vowels have developed from $V \eta$ sequences, as $V \eta$ sequences are attested for many of the gaps represented by a hyphen in Table 3. All attested VN sequences are shown in Table 6 , with marginal sequences in parentheses.

Comparing Tables 3 and 6 shows that nasalised vowels and $V \eta$

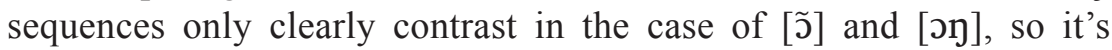


Table 6

VN sequences

\begin{tabular}{|c|c|c|c|c|c|c|c|c|c|}
\hline & \multicolumn{3}{|c|}{ Front } & \multicolumn{3}{|c|}{ Central } & \multicolumn{3}{|c|}{ Back } \\
\hline & Vm & Vn & $\mathrm{Vy}$ & Vm & Vn & $V \eta$ & Vm & Vn & Vy \\
\hline High & $\mathrm{im}$ & in & - & & & & - & - & un \\
\hline Mid-high & (em) & en & - & & & & - & - & on \\
\hline Central & & & & əm & (ən) & әฤ & & & \\
\hline Mid-low & $(\varepsilon \mathrm{m})$ & $\varepsilon n$ & - & & & & - & - & כฤ \\
\hline Low & & & & am & (an) & an & & & \\
\hline
\end{tabular}

possible that some nasalised vowels have indeed developed from $V \eta$ sequences. Furthermore, $V n$ and $V \eta$ are in near-complementary distribution, with [n] occurring after front vowels, and [ $\mathrm{y}]$ occurring after central or back vowels, since on and an are marginal and could be considered variant pronunciations of $\partial \eta$ and $a \eta$, which are both quite common. One could also say that the distinction between $\mathrm{Vm}$ and $V \eta$ is neutralised for back vowels.

\subsection{Comparative phonology within the (Bikwin-)Jen subgroup}

A typologically unusual feature of Kyak, and two other languages of the Jen cluster (Leelau and Tha), are the dental fricatives $[\theta]$ and [ð], which are often in free variation with $[\mathrm{s}]$ and $[\mathrm{z}]$ respectively. Some speakers use the dental fricatives more often, whilst others favour the alveolar fricatives, although the same speaker may use both interchangeably. The distinction may be influenced by how familiar speakers are with each of Kyak's two closest relatives, Moo and Leelau, since Leelau has the dental fricatives but Moo does not. In Doso and Dza, cognates of words with dental fricatives in Kyak often have [h], as shown in Table 7. 
Table 7

Jen cluster cognates of words with dental fricatives

\begin{tabular}{|c|c|c|c|c|c|}
\hline & Kyak & Moo & Leelau & Dza & Doso \\
\hline 'finish' & ðàm / zว̀m & zว̀m & ठ̀̀m & & \\
\hline 'walk' & ðうे / zذ̀ & $z \grave{j}$ & đàù & $h \bar{o}$ & hò \\
\hline 'kill' & 犭àb / zàb & zòp & ðâp & jà & $h^{j}$ ว̀ \\
\hline 'bag' & $\theta$ $\theta$ ว́ / sáó & & & ho: & \\
\hline 'buffalo' & $\theta \grave{\tilde{\varepsilon}} \grave{\tilde{\varepsilon}} / s \grave{\tilde{\varepsilon}} \grave{\tilde{\varepsilon}}$ & & & ha & \\
\hline 'fish' & Өáy / sáy & sán & Өán & $h^{j}$ ìn & yìn \\
\hline
\end{tabular}

Another typologically unusual feature found in several of the Jen languages is the presence of breathy vowels, ${ }^{4}$ although so far I have come across just a single word with a breathy vowel in Kyak: ṇ̣ṇ̣ 'four'. In this case, it seems that the breathy voice begins in the nasal segment and continues into the vowel, as can be seen in Figure 2.

The breathy voiced segments (on the left in Figure 2) are characterised by many of the typical acoustic correlates of breathy vowels. Firstly, the waveform for the breathy voiced segment (taken from part of the nasal consonant) is much more jagged than its modal counterpart, reflecting greater aperiodic noise from the airflow through the glottis. This can be seen by the high frequency grey areas in the spectrogram for the breathy voiced nasal segment as well. Secondly, the breathy voiced segments are of a lower intensity than the modal, seen in both the lower amplitude of the waveform and the relative paleness of the spectrogram. Thirdly, the modal segment has a visually well-defined nasal-to-vowel transition compared to the breathy version.

${ }^{4}$ Othaniel (2017) reports that breathy vowels occur in all the Jen languages except for Moo, but that it is difficult to reconstruct them across the cluster. Even in Dza, where they are perhaps most frequent, they still have a relatively small functional load. Furthermore, a scan of his comparative wordlist reveals that breathy vowels in Dza virtually all correspond to the devoicing of the preceding consonant in cognates from other Jen languages. 

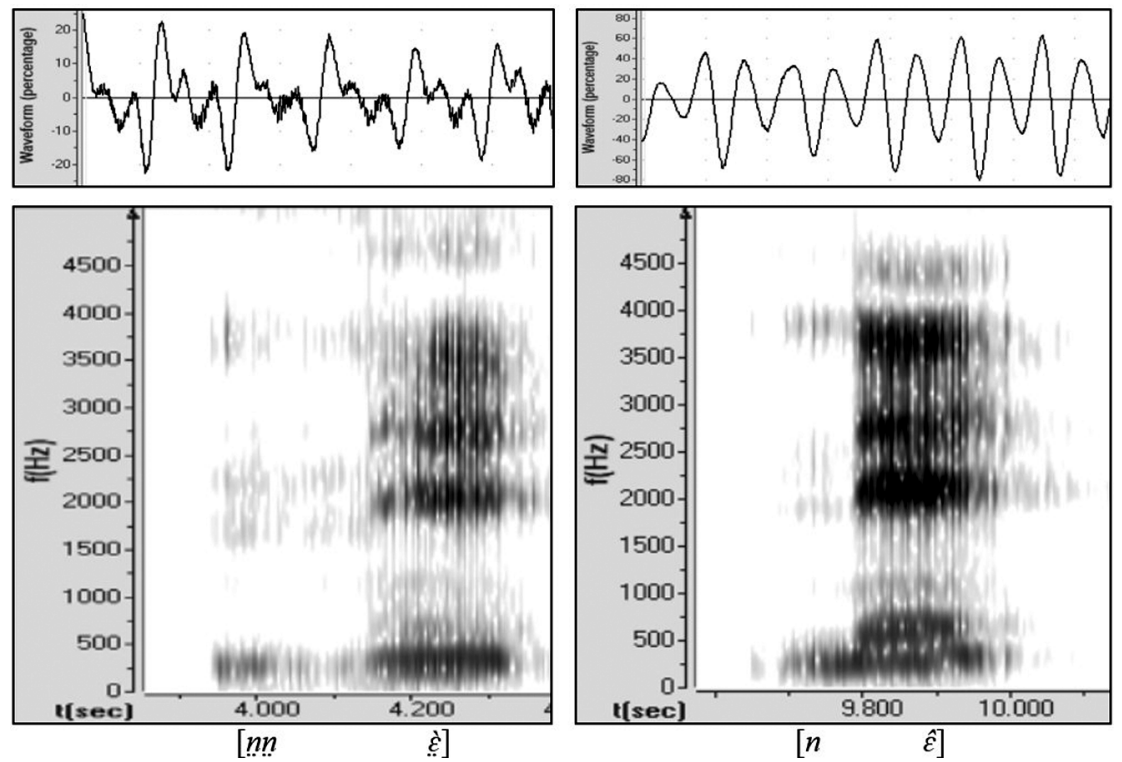

Figure 2. Waveforms and spectrograms of breathy and modal voiced segments in the Kyak words ṇ̣ṇ 'four' and $n \hat{\varepsilon}$ 'mother'

All three features are reported to be distinctive of breathy voiced phonation cross-linguistically (Gordon \& Ladefoged 2001).

\section{Nominal morphology}

The Jen languages do not show much evidence of noun classes, which are present in some other language groups in the area (e.g. Tula-Waja, Longuda and Bəna-Mboi (Kleinewillinghöfer 1996a: 94)). Nouns in Kyak are unmarked for number, and plural meaning is achieved either by means of plural modifiers (e.g. a numeral or other quantifier), as shown in (13).
(13)
a. kàp
'tree/trees'
b. $k \bar{a} p k^{w} i n$ 'one tree'
c. kàp t⿳亠े 'three trees'
d. kāp ńdê 'all trees' 
The sole exception to this in my data is the word káb 'bone', which forms it's plural by means of partial reduplication: ká-káb 'bones'. The two main examples of nominal morphology are with nominal modifiers and possessive constructions. These are dealt with in $\S 4.1$ and $\S 4.2$.

\subsection{Nominal modifiers}

Some nominal modifiers carry the prefix á(n)-. The function of this prefix appears to be to derive nominal modifiers, particularly from verbs. However, there are a few words with this prefix which denote basic quality concepts (e.g. 'good', 'bad', 'big') which do not have corresponding verbs, as shown in (14).
(14) a. kāp á-lāy 'good tree(s)'

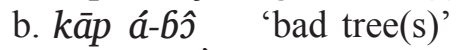
c. kāp ám-g̃̃̀ 'big tree(s)'

The á(n)- prefix can also attach to the numeral $k^{w}$ in 'one' to derive the specific determiner á $y-k^{w}$ in 'a certain', as shown in (15).
a. $k \bar{a} p k^{w i n} \quad$ 'one tree'
b. $k \bar{a} p$ án-kwin 'a certain tree'

It is also used in the formation of nominalised predicates with the structure object+verb, as shown in (16).
a. $i \quad{ }^{\downarrow} t a ́ \quad b^{w \longleftarrow}$
3PL fight war
'They fought a war.'
b. $b^{w} \hat{\imath} \quad a ́-t a ̂$
war MOD-fight
'war-fighting'

Words with the á- or án- prefix can never function as verbs, although they can function as nouns denoting an item characterised by 
a certain property (e.g. á-kū 'an old one'). Some lexical nouns can function as modifiers, but when they do, they always precede the head noun and never take the prefix á- or án-, and are thus formally identical to associative constructions (e.g. wì sém 'a small pot', lit. 'child of pot'). A few modifiers only occur before the head noun, as shown in (17), and cannot occur independently.
(17)
a. nùy bà 'old goat(s)'
b. zà kàp 'another tree'
c. $s^{w} \grave{a}$ kàp 'other trees'

Several modifiers carrying the á- or án- prefix can occur in a reduplicated form (with a change in tone) to indicate a comparative or more intense form, as shown in (18) and (19).
a. tāl á-dzin
'round stone(s)'
b. tāl á-brām
'smooth stone(s)'

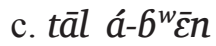
'heavy stone(s)'

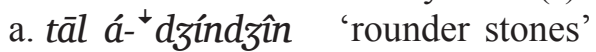

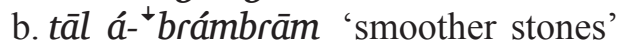
c. $t a \bar{l} a^{-}{ }^{\downarrow} b^{w} \dot{\varepsilon} n b^{w} \bar{\varepsilon} n \quad$ 'heavier stones'

(19)

For verbs which inherently involve an end result, the reduplicated forms are obligatory when functioning as modifiers, as shown in (20).
(20)
a. nám á- ${ }^{\downarrow} l i ̂ l i ̀ ~ ' b u r n t ~ m e a t ' \quad$ (cf. lì 'burn')
b. nám á-zúzû 'spoiled meat' (cf. zù 'become spoiled')
c. nám á-jójô 'cooked meat' (cf. jò 'cook')

\subsection{Possessive contructions}

The other main example of morphology within the noun phrase is in possessive constructions, in which the head noun carries a pronominal suffix/index. Furthermore, alienable possession is distinguished from inalienable possession by the morpheme $-g$ - which occurs between the 
head noun and the pronominal suffix. Inalienable possession is used for body parts and kinship terms, although it is optional for some kinship terms such as 6é 'husband' and sí 'wife'. The grammatical paradigms for each type of possession are shown in Tables 8 and 9. Note that for the first person singular in inalienable possession, the vowel of the pronominal suffix -ám assimilates to the preceding vowel.

\section{Inalienable possession}

\begin{tabular}{|c|c|c|c|c|}
\hline Pronoun & $s^{w} \grave{i}$ 'ear' & ná 'hand' & $g \hat{\tilde{\partial}}$ 'chest' & jồn 'brother' \\
\hline $1 \mathrm{sG}$ & $s^{w} \bar{z}-i ́ m$ & ná- ${ }^{\downarrow} a ́ m$ & 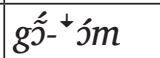 & jôn-ám \\
\hline $2 \mathrm{SG}$ & $s^{w} \bar{i}-m a ́$ & ná- ${ }^{\downarrow} m a ́$ & 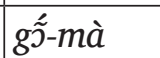 & jồ-má \\
\hline $3 \mathrm{SG}$ & $s^{w \bar{z}-u ́}$ & ná-ú & $g \tilde{\jmath}-{ }^{+} \tilde{\jmath}-$ & jôy-ú \\
\hline 1PL & 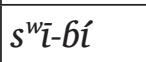 & $n e^{\downarrow}{ }^{\downarrow} 6 i^{-}$ & 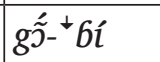 & jôn-6í \\
\hline $2 \mathrm{PL}$ & $s^{w} \bar{z}-6 a ́$ & ná-6á & gว̃́-6á & jồ-6á \\
\hline 3PL & $s^{w} \bar{i}-\dot{i}$ & $n e^{-}{ }^{\dagger} \hat{i}$ & $g \hat{\jmath}-{ }^{+} i$ & jôn-í \\
\hline
\end{tabular}

Table 9

Alienable possession

\begin{tabular}{|c|c|c|c|}
\hline Pronoun & jábē 'chicken' & Gál 'rope' & jám 'meat' \\
\hline $1 \mathrm{sg}$ & já6e- $-^{\downarrow} g-\bar{\partial} m$ & 6ál-g-ám & nám- ${ }^{\downarrow} g$-ám \\
\hline $2 \mathrm{sG}$ & 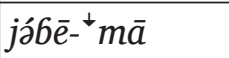 & Gál-má & nám- ${ }^{\star} m a ́$ \\
\hline $3 \mathrm{sG}$ & já6ē-g-â & 6ál-g-ûu & nám- ${ }^{\top} g-\hat{u}$ \\
\hline 1PL & 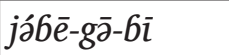 & 6ál-gá-6í & nám- ${ }^{\downarrow}$ gá-6í \\
\hline 2PL & já6ē-gz̄-6à & 6ál-gá-6à & 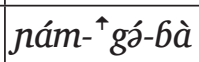 \\
\hline 3PL & jábēe-g-î & 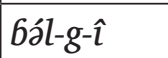 & nám- $^{\top} g-\hat{\imath}$ \\
\hline
\end{tabular}

There is a slight irregularity in the paradigm for alienable possession (Table 10) in that the morpheme $-g$ - is not used in the second person singular. Also, in the second and third person plural, the vowel [ə] is 
inserted between the $[\mathrm{g}]$ and the $[6]$, as $[\mathrm{g} 6]$ is not a phonologically permitted consonsonant combination.

If the possessor is expressed by a noun, there is no segmental difference between inalienable and alienable possession and the two nouns are simply juxtaposed (e.g. gṍ `dáúdà 'Dauda's chest', bál dáúdà 'Dauda's rope'), although it is possible, as this example shows, that inalienable possession is distinguished by downstep of the intial high tone of the second noun, implying the presence of a floating low tone between the two nouns.

\section{Verbal morphosyntax}

Kyak verbs exhibit four main types of morphosyntactic variation: object pro-indexes (bound person forms that cannot occur with a conominal object (Haspelmath 2013)); STAMP morphs (portmanteau morphs expressing Subject-Tense-Aspect-Mood-Polarity (Anderson 2012; 2015; 2016)), which in this case are used for expressing perfective and imperfective aspect; specific TAM morphs (for expressing progressive aspect and intended/imminent actions); and partial reduplication (for expressing definite future tense). These features are described in $\S 5.1-$ $\S 5.4$ respectively.

\subsection{Object pro-indexes}

Kyak uses argument indexes to express object arguments on verbs, and the set used is very similar to that used for possession as described in the previous section. According to the typology proposed by Haspelmath (2013), the object indexes in Kyak are pro-indexes, as they cannot occur with a conominal. Table 10 gives the pro-indexes used for four different lexical verbs: $6 i ́$ 'see', kám 'embrace', tj̀k 'push', and dò 'give'. Note that for the verb $6 i$, the vowel [ə] of the first person singular index -ám assimilates to the preceding vowel (i.e. 6í-ám $\rightarrow$ Giím), just as it did when functioning as a possessive index. However, for the verb dà 'give', the vowel of the index deletes rather than forming

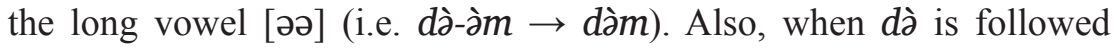


by any other vowel, the [ə] of the verb dà assimilates to the following vowel (e.g. dà-à $\rightarrow$ dàà). For the verb t’̀k 'push', the final [k] becomes voiced and spirantised when the object pro-index begins with a vowel (i.e. t’̀k-à $\rightarrow$ ṫ̀yà). Such phonological changes are evidence that the object pro-indexes are phonologically bound morphemes, as such rules do not always apply across word boundaries.

Table 10

\section{Object pro-indexes}

\begin{tabular}{|c|c|c|c|c|}
\hline & $\begin{array}{l}\text { 'he saw...' } \\
\text { (6í 'see') }\end{array}$ & $\begin{array}{l}\text { 'he embraced...' } \\
\text { (kám 'embrace') }\end{array}$ & $\begin{array}{l}\text { 'he pushed...' } \\
\text { (tjk' 'push') }\end{array}$ & $\begin{array}{l}\text { 'he gave...' } \\
\text { (dà 'give') }\end{array}$ \\
\hline $1 \mathrm{SG}$ & $u^{\star} 6 i ́-i ́ m$ & $u^{\downarrow} k a ́ m-a ́ m$ & ú tōy-àm & ú dò-m \\
\hline $2 \mathrm{sG}$ & $u^{\star}{ }^{\star} b i-a ́$ & $u^{\downarrow} k a ́ m-a ̀$ & ú $t \bar{\partial} \gamma-\bar{a}$ & ú dà-à \\
\hline $3 \mathrm{SG}$ & $u^{\star} 6 i ́-u ́$ & $u^{\downarrow}{ }^{\downarrow} k a ́ m-u ́$ & ú $t \bar{\jmath} \gamma-\bar{u}$ & ú dú-ù \\
\hline $1 \mathrm{PL}$ & $u^{\star} 6 i ́-6 i$ & $u^{\downarrow}{ }^{\downarrow} k a ́ m-6 i ̄$ & ú tók’ $-6 i ̄$ & 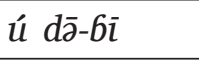 \\
\hline $2 \mathrm{PL}$ & $u^{\star}{ }^{\star} 6 i ́-6 a ́$ & $u^{\star}{ }^{\star} k a ́ m-6 a ́$ & ú tók $-6 \bar{a}$ & ú dá-6à \\
\hline 3PL & 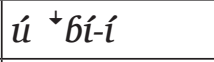 & $u^{\downarrow} k a ́ m-i ́$ & ú tóf-ī & ú dí-ì \\
\hline Noun & $u^{\star}{ }^{\star}$ Gí dáúdà & $u^{\downarrow}{ }^{\downarrow} k a ́ m$ dáúdà & ú ts̄kำ dāūdà & ú dò dāūdà \\
\hline
\end{tabular}

For verbs which end in bilabial stops [p] or [b], the final consonant is deleted when followed by a vowel-initial index, as shown in Table 11 for the verbs gbə̀p 'hit' and zàb 'kill' (i.e. ż̀b-ว̀m $\rightarrow$ zà̀ेm - note that a long [əə] is permitted in this case). In addition, an /ə-u/ sequence becomes [oo] in the third person singular (i.e. ż̀b-ú $\rightarrow z \bar{o} \bar{o}$, and an $/ \partial-\mathrm{i} /$ sequence becomes [ei] in the third person plural (i.e. zàb-i $\rightarrow$ $z \bar{e} \bar{\imath})$. When compared with the corresponding changes for the verb dì

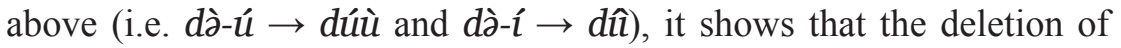
a final [p] or [b] has an impact on the vowel quality as well.

\subsection{STAMP morphs (perfective and imperfective)}

STAMP morphs are common across the Macro-Sudan Belt and typically combine with a following verb to encode a combination of tense-aspect- 
Table 11

Object pro-indexes for verbs with a final bilabial stop

\begin{tabular}{|c|c|c|}
\hline & $\begin{array}{l}\text { 'he hit...' } \\
\text { (gbàp 'hit/beat') }\end{array}$ & $\begin{array}{l}\text { 'he kill...' } \\
\text { (zàb 'kill') }\end{array}$ \\
\hline $1 \mathrm{SG}$ & $u^{\downarrow}$ gbá-ám & ú zว̀-ว̀m \\
\hline $2 \mathrm{SG}$ & $u^{\downarrow} g b a ́-a ́$ & ú zà-à \\
\hline $3 \mathrm{SG}$ & ú gbò-ō & $u ́ z \bar{o}-\bar{o}$ \\
\hline $1 \mathrm{PL}$ & ú gb̀̀p-6ī & ú zàb $b^{\urcorner}-6 \bar{\imath}$ \\
\hline 2PL & ú gbàp-6ā & ú zว̀b $-6 \bar{a}$ \\
\hline $3 \mathrm{PL}$ & ú gbè-ī & $u ́ z \bar{e}-\bar{\imath}$ \\
\hline Noun & ú gfàp dāūdà & ú zàb $b^{\urcorner}$dāūdà \\
\hline
\end{tabular}

mood and person/number (Anderson 2016: 515). Kyak uses the STAMP morph + floating low tone construction to encode both perfective and imperfective aspect, the difference between them being in the length of the STAMP morph. The floating low tone causes downstep when trapped between two high tones, otherwise it is absorbed by an adjacent low tone, as shown in Table 12. When the subject argument is a noun, it replaces the STAMP morph, although the floating low tone remains.

Table 12

Paradigm for perfective aspect

\begin{tabular}{|c|c|c|}
\hline & $t \varepsilon ́$ 'go' & Gloss \\
\hline $1 \mathrm{SG}$ & $\grave{n} t \varepsilon$ & 'I went' \\
\hline $2 \mathrm{SG}$ & à $t \varepsilon$ & 'you (sg) went' \\
\hline $3 \mathrm{SG}$ & $u^{\downarrow} t \varepsilon^{\prime}$ & 'he/she went' \\
\hline 1PL & $6 i ̀ t \varepsilon$ & 'we went' \\
\hline $2 \mathrm{PL}$ & $6 a^{\star} t \varepsilon^{\prime}$ & 'you (pl) went' \\
\hline 3PL & $i^{\downarrow} t \varepsilon^{\prime}$ & 'they went' \\
\hline Noun & dáúdà té & 'Dauda went' \\
\hline
\end{tabular}


For imperfective aspect, the STAMP morphs màn- and màà- are used in the first and second person singular, whilst the vowel of the STAMP morph is lengthened in other cases, as shown in Table 13. For noun subjects, an à- prefix appears to be optional before the verb.

Table 13

\section{Paradigm for imperfective aspect}

\begin{tabular}{|c|c|c|}
\hline & té 'go' & Gloss \\
\hline $1 \mathrm{sG}$ & màn té & 'I go' \\
\hline $2 \mathrm{SG}$ & màà té & 'you (sg) go' \\
\hline $3 \mathrm{SG}$ & 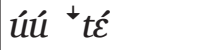 & 'he/she goes' \\
\hline $1 \mathrm{PL}$ & bì̀ té & 'we go' \\
\hline 2PL & Gáá ${ }^{\downarrow} t \varepsilon$ & 'you (pl) go' \\
\hline 3PL & $\ddot{i}{ }^{\downarrow} t \varepsilon$ & 'they go' \\
\hline Noun & dáúdà (à)-té & 'Dauda goes' \\
\hline
\end{tabular}

\subsection{TAM morphs (progressive)}

The imperfective form is typically used to encode habitual and indefinite future situations, but it is possible that it originally covered progressive meaning as well, as imperfectives often do cross-linguistically (Bybee et al. 1994: 125-126). ${ }^{5}$ However, Kyak has a distinct progressive construction involving the copula verb ḋ̀, which occurs after a nominal subject but before a pronominal subject, as shown in Table 14. Once again, the final [ə] of the progressive morpheme dà assimilates to an immediately adjacent vowel (i.e. dà-ú $\rightarrow$ dùú).

The only other verb in my data that can occur clause-initially is the verb tábá 'be going to'. With this verb, a pronominal subject may

${ }^{5}$ The imperfective could thus be considered what Dahl (2008: 10) refers to as a "doughnut gram", namely an older form that has had its semantic centre invaded by a younger one, and has lost some of its prototypical uses. Thanks to Raimund Kastenholz for drawing my attention to this. 
Table 14

Paradigm for progressive aspect

\begin{tabular}{|c|c|c|}
\hline & $t \varepsilon^{\prime}$ 'go' & Gloss \\
\hline $1 \mathrm{SG}$ & d’̀-n té & 'I am going' \\
\hline $2 \mathrm{SG}$ & d’̀-mà té & 'you (sg) are going' \\
\hline $3 \mathrm{sG}$ & dùú ${ }^{\downarrow} t \varepsilon ́$ & 'he/she is going' \\
\hline 1PL & dà-6ì té & 'we are going' \\
\hline $2 \mathrm{PL}$ & dà-6á té & 'you (pl) are going' \\
\hline 3PL & dìi té & 'they are going' \\
\hline Noun & dáúdà dà té & 'Dauda is going' \\
\hline
\end{tabular}

appear either side of the verb, without any noticeable change in meaning, as shown in examples (21) and (22).

(21) tá6á-n

be_going_to-1SG.PFV

'I am going to tell a story.'

ì-tábá

1SG.PFV-be_going to tell story

'I am going to tell a story.'

\subsection{Reduplication (definite future)}

Although imperfective aspect is the usual form used to encode future events, Kyak has a less common future form involving reduplication, used to express more certainty about a future event. The reduplicated future uses the same STAMP morphs as the imperfective, with the addition of a Ca- prefix between the STAMP morph and the verb, where $C$ is a copy of the first consonant of the verb. Examples are given in Table 15, using the verbs té 'go' and zò 'walk'.

If the verb carries an object index, then the reduplicated element occurs after the object index together with a copy of the verb, rather than between the STAMP morph and the verb. The contrast between 
Table 15

Paradigm for definite future tense

\begin{tabular}{|c|c|c|c|c|}
\hline & té 'go' & Gloss & zذ̀ 'go' & Gloss \\
\hline $1 \mathrm{SG}$ & màn tà-té & 'I will go' & màn zà-zó & 'I will walk' \\
\hline $2 \mathrm{SG}$ & màà tà-té & $\begin{array}{l}\text { 'you (sg) } \\
\text { will go' }\end{array}$ & màà zò-zó & $\begin{array}{l}\text { 'you (sg) will } \\
\text { walk' }\end{array}$ \\
\hline $3 \mathrm{SG}$ & úú tò-tè & 'he/she will go' & úú ż̀-zj̀ & 'he/she will walk' \\
\hline 1PL & bì̀ tà-tর́ & 'we will go' & bì zว̀-zj́ & 'we will walk' \\
\hline $2 \mathrm{PL}$ & Gáá tà-tc̀ & $\begin{array}{l}\text { 'you (pl) } \\
\text { will go' }\end{array}$ & 6áá zà-zj̀ & $\begin{array}{l}\text { 'you (pl) will } \\
\text { walk' }\end{array}$ \\
\hline $3 \mathrm{PL}$ & î́ tà-tè & 'they will go' & î́ zว̀-zj̀ & 'they will walk' \\
\hline Noun & $\begin{array}{l}\text { dáúdà } \\
\text { (à)-tà-té }\end{array}$ & $\begin{array}{l}\text { 'Dauda } \\
\text { will go' }\end{array}$ & $\begin{array}{l}\text { dáúdà } \\
\text { (à)-zว̀-zj́ }\end{array}$ & 'Dauda will walk' \\
\hline
\end{tabular}

the default future and the definite future for the verb gbàp 'hit/beat' is shown in (23). Note that the object index affects the vowel of the verb (i.e. gbàp-ú $\rightarrow$ gbòó), as described in $§ 5.1$.

(23) a. màn gbò-ó

1SG.IPFV hit-3SG.OBJ

'I (will) hit him.'
b. màn
gbò-ó
gbà-gbàp
$1 \mathrm{SG} . \mathrm{IPFV}$
hit-3SG.OBJ
RED-hit
'I will (certainly) hit him.'

The full paradigm for the definite future form is shown in Table 16.

Table 16

Paradigm for definite future tense for verbs with object indexes

\begin{tabular}{|l|l|l|}
\hline & gbàp 'hit/beat' & Gloss \\
\hline 1sG & màn gbò-ó gbà-gbàp & 'I will beat him' \\
\hline 2sG & màà gbò-ó gbò-gb̀̀p & 'you (sg) will beat him' \\
\hline
\end{tabular}


End of Table 16

\begin{tabular}{|c|c|c|}
\hline & gbàp 'hit/beat' & Gloss \\
\hline $3 \mathrm{SG}$ & úú gbò-ó gbà-gbàp & 'he/she will beat him' \\
\hline $1 \mathrm{PL}$ & bì̀ gbò-ó gbà-gbàp & 'we will beat him' \\
\hline $2 \mathrm{PL}$ & Gáá gbò-ó gbà-gbàp & 'you (pl) will beat him' \\
\hline $3 \mathrm{PL}$ & î gbò-ó gbò-gbàp & 'they will beat him' \\
\hline Noun & dáúdà (à) gbò-ó gbà-gbàp & 'Dauda will beat him' \\
\hline
\end{tabular}

\section{Assertiveness and epistemicity}

Another morph that can attach to verbs is the epistemic marker $-\eta$, which occurs only in the perfective construction in my data, and is usually, if not always, grammatically optional. It typically expresses a high degree of certainty about a proposition, as shown by (24) and (25).

(24) $u ́$

\section{${ }^{\star}$ tá àbūdzā}

3SG.PFV go Abuja

'He went to Abuja.' (I'm just telling you)

(25) ú

$$
{ }^{\star} t a ́-\eta \quad a ̀ b \bar{u} d z \bar{a}
$$

3SG.PFV go-ASS Abuja

'He did go to Abuja.' (somebody is doubting it, but I'm reassuring them)

The clitic $-\eta$ occurs after any core arguments but before any adjuncts (e.g. non-core arguments or prepositional phrases). For example, in (25), the noun 'Abuja' is a non-core argument (with the thematic role of GOAL), and so $-\eta$ attaches directly to the verb. In (26), on the other hand, 'Peter' is a core argument (object), and so $-\eta$ attaches to the noun 'Peter'.

(26) $\bar{m}$

bí pítà- $\bar{y}$

1sG.PFV see Peter-ASS

'I have seen Peter.' 
In narratives, $-\eta$ can be used to highlight a particular action or a component of an action, as shown in (27). In this example, the speaker is emphasising the fact that he (hare) really had searched thoroughly all over the place. Here $-\eta$ is represented by its allomorph $-m$, which occurs before bilabial consonants.

\section{ú $\quad{ }^{\downarrow}$ tá-m plè $\bar{n} d \hat{e}$}

3SG.PFV go-ASS place all

'He really went everywhere.'

A similar, and possibly related morpheme, that appears to be connected with the idea of assertiveness is the clause-final morpheme jây, ${ }^{6}$ which means something like 'for sure' and adds a belief in the the certainty of the proposition. Indeed, $-\boldsymbol{\eta}$ can sometimes be substituted with jây without any noticeable difference in meaning. jây often occurs in the denouement or resolution of narratives, as in (28), in which the strands of the plot are drawn together and matters are explained and resolved, or in the performative ending of folktales, as in (29):

(28)
ú jìk
ú ‘pál
$i$
jây

3SG.PFV be_clever 3SG.PFV pass 3sG.LOG for_sure

'He (dove) was clever (and) had surpassed him (hare) for sure.'

(29) mùmẁ̀n tá $b^{w} \grave{a}$ mìún jây

story go hole crab for_sure

'My story has entered the hole of a crab (i.e. come to an end).'

\section{Logophoric pronouns}

Logophoric pronouns have been defined as third person pronouns that occur in indirect or semi-direct thoughts or speech and which refer to the speaker of the represented speech (Pearson 2015: 77-78). In African

${ }^{6}$ An identical clause-final morpheme also occurs in Dza with a similar meaning. There, it is often glossed as 'completive', although its distribution suggests that its function is somewhat different. 


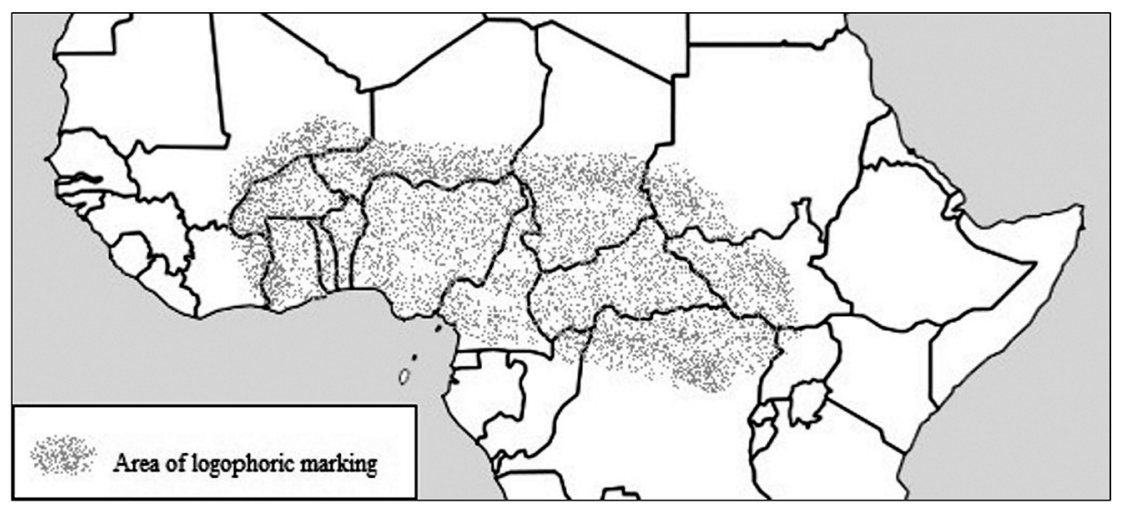

Figure 3. Logophoric pronouns in Africa (adapted from Storch 2018: 612)

languages, they are often motivated not by the information properties of the reported thoughts or speech, but by the discourse properties of the participants involved (Nikitina 2012: 282). They are extremely common in northern sub-Saharan Africa, as shown in Figure 3.

The only logophoric pronoun that has been identified so far in Kyak is the singular pronoun $i$ which can function either as subject or object within the embedded represented speech. If the default third person pronoun $u$ occurs in the represented speech, then it always refers to someone other than the speaker. This is shown in (30), in which the logophoric pronoun $i$ refers to the speaker, whereas the default third person singular object pronoun $u$ refers to someone else (in this case, the addressee). The reported speech content is shown within curly brackets.

(30) ú

$\bar{a} g \bar{\partial} \quad\{\hat{\imath}$

$m^{w} \dot{\varepsilon} n \quad u ́$

jây\}

3SG.PFV QUOT 3SG.LOG thank 3sG.OBJ for_sure

' $\mathrm{He}_{\mathrm{i}}$ (said) that he ${ }_{\mathrm{i}}$ thanked him $\mathrm{j}_{\mathrm{j}}$ for sure.'

In (31) by contrast, there is no logophoric pronoun, since the reported speech does not contain a pronoun referring back to the speaker: 


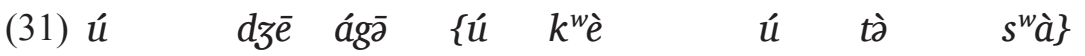 3SG.PFV say QUOT 3sg shrink.SBJV 3sG go.SBJV down 'He $\mathrm{i}_{\mathrm{i}}$ said that he $\mathrm{j}_{\mathrm{j}}$ should squat down.'}

Logophoric pronouns are a useful way of keeping track of third person referents in reported speech, especially when the speech clauses are quite long. Example (32) contains a sentence comprising six clauses of embedded speech, the third of which is itself an embedded speech clause). The last line contains three default pronouns $u$ and one logophoric pronoun $i$, which refers right back to sábè 'hare' at the beginning of the first clause. The logophoric pronouns and their coreferent are marked in bold:

(32) sábè $d z \bar{e}$ ágā $\{\bar{m}$ béà

hare say QUOT 1SG be_sorry

'Hare said, "I'm sorry".'

dì-ì $\quad d z \bar{e}$ ágā $\quad\{i ̀ \quad$ gám jìk ǹdé jây\}

PROG-3SG.LOG Say QUOT 3SG.LOG collect cleverness all for_sure 'He (Hare) was thinking that he (Hare) had collected all the cleverness.'

árè sō̄o rì, níjày já

part one remain and_so CONJ

'But there was one left, and so'

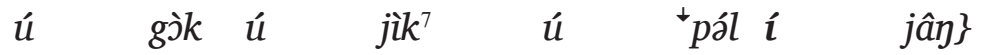

3SG.PFV dove 3sG.PFV be.clever 3sG.PFv pass 3sG.LOG for_sure 'He, Dove, was cleverer than him (Hare) for sure.'

In the last line, the initial phrase ú gìk 'He, Dove' is not strictly necessary for referent disambiguation but is included as a way of highlighting that Dove was the one who was the cleverest, and not Hare, as Hare had previously thought.

${ }^{7}$ The verb jik 'be clever' has an identical nominal form jik 'cleverness'. 


\section{Conclusion}

This paper has provided the first insights into a few of the phonological and morphosyntactic features of Kyak, one of ten almost completely undocumented languages of the Jen cluster. The basic segmental phonology has been described, revealing some typologically unusual segments like the voiced and voiceless dental fricatives, and the occasional breathy vowel, although both these features are also found in other languages of the Jen cluster. Labio-velar consonants are also attested, being one of the areal features found in languages of the Macro-Sudan Belt (Güldemann 2008). The language has an eight vowel system and no significant vowel harmony, with the central vowel /a/ being realised as $[\varepsilon]$ before pause.

Nominal morphology is minimal, with no noun-class affixes, which are common in other Adamawa languages like Tula, Waja and Longuda. The main examples of nominal morphology are certain modifiers, and possessive constructions, which show a distinction between alienable and inalienable possession. There is a little more morphology on the verb, with some verbs showing suppletive forms when affixed by vowel-initial object pro-indexes. There are two future tenses, a default form and a reduplicated form indicating more certainty about a future event, as well as imperfective, perfective and progressive aspects.

At the clausal level, noteworthy is the presence of an epistemic clitic which expresses a high degree of certainty in the proposition. Another epistemic morpheme is the clause-final word jây, which also appears to indicate a strong commitment by the speaker to his/her belief in the proposition. Kyak also has logophoric pronouns, which are widespread in the languages of northern sub-Saharan Africa.

It is hoped that these intitial findings, admittedly rather fragmentary, will provide insights into and stimulate further research on the Jen cluster languages, and indeed in other Adamawa languages, which still remain one of Africa's least documented language families. 


\section{Abbreviations}

1 - first person

2 - second person

3 - third person

ASs - assertive

CONJ - conjunction

DEM - demonstrative

IPFV - IMperfective
LOC - locative

LOG - logophoric

MOD - modifier

OBJ - object

$\mathrm{PFV}$ - perfective

PL - plural

POSs - possessive
PROG - progressive

QUOT - quotative

RED - reduplication

SBJV - subjunctive

SG - singular

\section{References}

Adelberger, Jörg. 1995. Zum Verhältnis von Sprache, Ethnizität und Kultur in den Muri-Bergen Nordost-Nigerias. In Fleisch, Axel \& Otten, Dirk (eds.), Sprachkulturelle und historische Forschungen in Afrika, 13-27. Cologne: Rüdiger Köppe Verlag.

Anderson, Gregory D. S. 2012. S/TAM/P morphs in the history of BenueCongo and Niger-Congo conjugation. (Paper presented at Niger-Congress, Paris, September 2012.)

Anderson, Gregory D. S. 2015. STAMP morphs in Central Sudanic languages. In Mietzner, Angelika \& Storch, Anne (eds.), Nilo-Saharan: Models and descriptions, 151-167. Köln: Rüdiger Köppe Verlag.

Anderson, Gregory D. S. 2016. STAMP morphs in the Macro-Sudan Belt. In Payne, Doris L. \& Pacchiarotti, Sara \& Bosire, Mokaya (eds.), Diversity in African languages, 513-539. Berlin: Language Science Press.

Blench, Roger. 2019. An Atlas of Nigerian Languages. Unpublished manuscript.

Bybee, Joan \& Perkins, Revere \& Pagliuca William. 1994. The evolution of grammar: Tense, aspect, and modality in the languages of the world. Chicago: University of Chicago Press.

Dahl, Östen. 2000. The tense-aspect systems of European languages in a typological perspective. In Dahl, Östen (ed.), Tense and aspect in the languages of Europe, 3-25. Berlin: de Gruyter.

Eberhard, David M. \& Simons, Gary F. \& Fennig, Charles D. (eds.). 2019. Ethnologue: Languages of the world. $22^{\text {nd }}$ edition. Dallas, Texas: SIL International. (https://www.ethnologue.com/language/BKA) (Accessed 2019-12-21.) 
Gordon, Matthew \& Ladefoged, Peter. 2001. Phonation types: a crosslinguistic overview. Journal of phonetics 29(4), 383-406.

Güldemann, Tom. 2008. The Macro-Sudan belt: Towards identifying a linguistic area in northern sub-Saharan Africa. In Heine, Bernd \& Nurse, Derek (eds.), A linguistic geography of Africa, 151-185. Cambridge: Cambridge University Press.

Hammarström, Harald \& Forkel, Robert \& Haspelmath, Martin. 2019. Glottolog 4.1. Jena: Max Planck Institute for the Science of Human History. (http://glottolog.org) (Accessed 2019-12-21.)

Haspelmath, Martin. 2013. Argument indexing: a conceptual framework for the syntactic status of bound person forms. In Bakker, Dik \& Haspelmath, Martin (eds.), Languages across boundaries: Studies in memory of Anna Siewierska, 197-226. Berlin and Boston: Mouton De Gruyter.

Kleinewillinghöfer, Ulrich. 1995/2015. Bikwin-Jen Comparative wordlist (Swadesh 100). (https://www.blogs.uni-mainz.de/fb07-adamawa/files/ 2011/11/Bikwin-Jen-comparative-wordlist-100.pdf) (Accessed 201912-21.)

Kleinewillinghöfer, Ulrich. 1996a. Die nordwestlichen Adamawa-Sprachen Eine Übersicht. In Seibert, Uwe (ed.), Afrikanische Sprachen zwischen Gestern und Morgen, 80-103. Cologne: Rüdiger Köppe Verlag. (Frankfurter Afrikanistische Blätter 8.)

Kleinewillinghöfer, Ulrich. 1996b. Relationship between Adamawa and Gur languages: The case of Waja and Tula. Gur Papers / Cahiers Voltaïques $1,25-45$.

Kleinewillinghöfer, Ulrich. 2019. Is there a "Waja-Jen"? Paper presented at a round-table discussion at the Adamawa Conference, Johannes Gutenberg University, Mainz, Germany, 9-11 September 2019.

Nikitina, Tatiana. 2012. Logophoric discourse and first person reporting in Wan (West Africa). Anthropological Linguistics 54(3), 280-301.

Norton, Russell. 2019. The Jen cluster: Comparative analysis of wordlists.

Paper presented at the Adamawa Conference, Johannes Gutenberg University, Mainz, Germany, 9-11 September 2019.

Othaniel, Nlabephee. 2017. A phonological comparative study of the Jen language cluster. Bukuru, Nigeria: Theological College of Northern Nigeria. (B.A. dissertation).

Pearson, Hazel. 2015. The interpretation of the logophoric pronoun in Ewe. Natural Language Semantics 23, 77-118. 
Storch, Anne. 2018. Evidentiality and the expression of knowledge: An African perspective. In Aikhenvald, Alexandra Y. (ed.), The Oxford handbook of evidentiality, 610-628. Oxford: Oxford University Press.

World Bank Group. 2019. Population growth (annual \%) Nigeria. https:// data.worldbank.org/indicator/SP.POP.GROW? contextual=default\& end $=2018 \&$ locations $=$ NG\&start $=1960 \&$ view $=$ chart $\quad$ (Accessed 201912-21.) 